\title{
Hemodiyaliz Tedavisi Alan Hastalarda Semptom ve Konfor İlişkisi The Relationship of Symptoms and Comfort in
Patients Receiving Hemodialysis
} Canselin ALKIN DEMIR ${ }^{1}$ iD , Zülfünaz ÖZER ${ }^{2}$ iD

\section{Özet}

Amaç: Bu çalışma hemodiyaliz tedavisi alan hastalarda yaşanan semptomların konfor düzeyine etkisini incelemek için yapılmıştır.

Gereç ve Yöntemler: Tanımlayıcı ve kesitsel tipteki bu araştırma, İstanbul'daki bir diyaliz merkezinde hemodiyaliz tedavisi alan 192 hasta ile gerçekleştirildi. Veriler, "Hasta Tanıtım Formu", "Diyaliz Semptom İndeksi" ve "Hemodiyaliz Konfor Ölçeği”’ ile yüz yüze görüşme yoluyla toplandı.

Bulgular: "Diyaliz Semptom İndeksi" ortalaması 18,9 $\pm 10,31$;

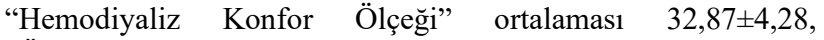
"Üstesinden Gelme" alt boyut ortalamas1 20,51 $\pm 2,91$ ve "Rahatlama" alt boyut ortalamas1 12,36 $\pm 2,6$ bulundu. Bacaklar1 hareketsiz tutmada zorlanma, bacakta şişlik, ayakta uyuşukluk, kas krampları, kaygılı olma, endişelenme, konsantre olmada zorluk, sinirli olma, üzgün olma, kusma, bulantı, iştahsızlık, kabızlık, ishal, ağız kuruluğu semptomlarını yaşama ile "Hemodiyaliz Konfor Ölçeği" arasında negatif yönde ve anlamlı ilişki saptand1.

Sonuç: Hastaların düşük semptom şiddetine, orta seviyede konfor düzeyine sahip olduğu saptandı. Hastaların yaşadıkları semptomların (kas iskelet sistemi, emosyonel, gastrointestinal sistem) konfor düzeyini olumsuz yönde etkilediği belirlendi.

Anahtar Kelimeler: Hemodiyaliz; Konfor; Semptom; Hemşirelik.

\begin{abstract}
Aim: The study aimed to investigate the effect of experienced symptoms on the comfort of hemodialysis receiving patients.

Materials and Method: This descriptive and cross-sectional study was conducted with 192 patients receiving hemodialysis treatment in a Dialysis Center in Istanbul. Data were collected with Patient Information Form, Dialysis Symptom Index and Hemodialysis Comfort Scale by face-to-face interview.
\end{abstract}

Findings: Mean Dialysis Symptom Index score was 18.9 \pm 10.31 ; mean Hemodialysis Comfort Scale score was $32.87 \pm 4.28$, mean Overcoming subscale score was found as $20.51 \pm 2.91$ while mean Relief subscale score was found as $12.36 \pm 2.6$. It was determined that variables of leg strain during inactivity,leg swelling, numbness in feet, muscle/cramp, having worry, anxiety, difficulty in concentrating, nervousness, sadness, vomiting, nausea, loss of appetite, constipation, diarrhea, mouth dryness, which patients experienced, had a negative and significant effect on Hemodialysis Comfort Scale.

Conclusion: Symptom severity of the patients was determined to be low while comfort levels were moderate. Symptoms experienced by patients (muscle- skeletal system, emotional, gastrointestinal system) negatively affect the comfort level.

Key Words: Hemodialysis; Comfort; Symptom; Nursing.

Geliş Tarihi / Submitted: 22 Ocak/Jan 2022 Kabul Tarihi / Accepted: 30 Ocak/Jan 2022

${ }^{1}$ Hemşire- İstanbul Sabahattin Zaim Üniversitesi, Lisansüstü Eğitim Enstitüsü, Hemşirelik AD, İstanbul, Türkiye

${ }^{2}$ Dr.Öğr. Üyesi- İstanbul Sabahattin Zaim Üniversitesi, Sağlık Bilimleri Fakültesi, Hemşirelik Bölümü, İstanbul, Türkiye

İletişim yazarı / Correspondence author: Zülfünaz ÖZER / E-posta: zulfinazozer@ gmail.com, Adres: İstanbul Sabahattin Zaim Üniv., Sağlık Bilimleri Fakültesi, Hemşirelik Bölümü, Halkalı, Küçükçekmece, İstanbul, Türkiye.

Bu makale Canselin ALKIN DEMIR'in yüksek lisans tezinden üretilmiştir. 


\section{GíRiş}

Kronik böbrek yetmezliği (KBY), böbrek hasar olmaksızın glomerüler filtrasyon hızının (GFH) üç aydan fazla süredir $60 \mathrm{ml} / \mathrm{dk} / 1,73 \mathrm{~m}^{2}$ den azalma ya da GFH'de düşmeye bakılmaksızın böbrekte üç aydan daha fazla süren işlevsel ve yapısal bozukluk olarak tanımlanmaktadır (1). Türk Nefroloji Derneği'nin 2020 verilerine göre hemodiyaliz (HD), son dönem böbrek yetmezliğinde en çok tercih edilen $(\% 72,66)$ renal replasman tedavi yöntemidir (2). HD, hastadan alınan kanın vasküler bir giriş yolu aracılığ 1 ile bir makinede sıv1 ve elektrolitlerin düzenlenerek, üre gibi atık maddelerin temizlenerek hastaya geri verilmesi işlemidir (3). HD tedavisi ile böbrek yetmezliğine bağlı belirti ve bulgular kontrol altına alınırken, hastaların yaşam süresi uzamakta, mortalite ve morbidite oranlarının azaltılması hedeflenmektedir (4,5). Ancak HD tedavisi uygulanan hastalar kabızlık, ishal, bulantı, iştahsızlık, kas kasılması, ödem, nefes darlığı, yorgunluk, uykusuzluk, kemik veya eklemlerde ağrı, kuru cilt, kaşıntı ve cinsel işlev bozukluğu gibi çok çeşitli semptomlarla baş etmek zorunda kalmaktadır (6,7). Bu semptomlara ek olarak, HD'ye bağlı fiziksel yetersizlikler ve hayatta kalmak için hemodiyaliz makinesine bağımlılık, ailevi rollerde değişiklik, iş ve sosyal yaşamda kısıtlamalar, beden imajında değişimler, iç çatışmalar, kaygı ve gelecek korkusu gibi fiziksel, psikolojik, sosyal ve ekonomik problemler ortaya çıkabilmektedir (7). Tüm bu etkenler bireylerin öz bakım gücünü, günlük yaşam aktivitelerini ve konforunu olumsuz olarak etkilemektedir (5).

"Konfor" kavramı, Latince "güçlendirmek" anlamına gelen "confortare" kelimesinden türetilmiştir. Konfor kavramı, Florence Nightingale'in yaptığ 1 çalışmalara kadar uzanmakta olup hemşire kuramcıların yayınlarında da yer almaktadır $(8,9)$. Hemşirelerin görevleri arasında yer alan rahatlatma fonksiyonunun üzerine temellenen konfor kuramını Teorisyen Katharine Kolcaba geliştirmiștir (10). Konfor karmaşık, çok boyutlu bir yapıdır ve temel bir insan ihtiyacıdır. Kolcaba konforu, dört boyutta (fiziksel, psiko-ruhsal, sosyokültürel ve çevresel) ele alınan ve temel insan ihtiyaçları olan rahatlama, ferahlama ve sorunların üstesinden gelme ile güçlenmiş hissetmenin deneyimi olarak tanımlamaktadır (11). Konfor Kuramı'nın, rahatlama (ease), ferahlama (relief), üstünlük (transcendence) olmak üzere üç düzeyi bulunmaktadir. Rahatlama; hasta bireyin rahatlamas1 ve memnun olduğunu belirtmesi durumudur. $\mathrm{Bu}$ ihtiyacı karşılamak için rahatsızlık yaratan faktörlerin ele alınması gerekmektedir. Hasta bireylerin gereksinimlerini karşılamaya temellenen ve hemşirelik kuramlarından temelini alan ferahlama; bireyin gereksinimlerinin karşılanması sonucunda sıkıntıdan kurtulmasıyla hissettiği durum olarak tanımlanmaktadır. Üstünlük, bireylerin sorunların üstesinden gelmesi, mevcut güçlerini artırmak olarak ifade edilmektedir. Konfora yönelik ihtiyaçları tam anlamıyla karşılanmış bireyler, sorunların üstesinden gelme düzeyine ulaşabilmektedir $(8,9)$. Üstünlük daha yüksek bir rahatlık durumu olarak tanımlanmakta ve onu sağlamak için sürekli eğitim ve motivasyon gerekmektedir (10).

Hemşirelik girişimlerinin başarılı olması için, hemşirelerin hastaların karşılanmayan ihtiyaçlarını karşılamak, maksimum rahatlığı sağlamak ve teşvik etmek için hastaların kapsamlı ve bütüncül bakıma ihtiyac1 olduğunun farkında olması gerekmektedir (10). Konfor, kaliteli hemşirelik bakımının temeli olarak kabul edilmektedir (8-10). Hemşirelerin, hastaların konforunu bozan etkenleri tespit edip ortadan kaldırarak hastaların güçlenmesine ve yenilenmesine yardımcı olmaları gerekmektedir (9). Konfor Kuramı hemşirelik tanı listesinde ("Kuzey Amerika Hemşirelik Tanıları Birliği SınıflandırmasıNANDA") "rahatsılık/konforda bozulma" olarak yer almaktadır (12). Hemşirelik süreci doğrultusunda verilecek bakımda, "Konfor Kuramı" rehber alınarak, bireylerin gereksinimlerine ilişkin veriler toplanmalı, karşılanamayan gereksinimler için konfor düzeyini arttırıcı hemşirelik girişimleri planlanarak bireylere özgü bütüncül bakım verilmelidir. Böylece optimum düzeyde konforun sağlanmas1 mümkün olacaktır (13).

Hemodiyaliz tedavisi uygulanan hastalarda anksiyete, otonomi kaybı, HD seansları, günlük yaşam aktivitelerini yerine getirememe, aile bireylerinin 
destek görmemesi gibi birçok faktör nedeniyle konfor bozulabilmektedir (14). HD alan hastalarda artan konfor, sağlık arama davranışlarına yol açmak-tadır. Ayrıca olumlu hasta sonuçlarına, daha iyi tedavi uyumuna, azalan diyaliz sürelerine, azalan diyalizat kullanımına, azalan hemşirelik girişimle-rine ve hastalar için genel olarak iyileştirilmiş yaşam deneyimi sağlamaktadır. Konfor düzeylerinin artması, daha düşük komorbidite ve mortalite oranlarına ve kurumsal hasta sonuçlarında iyileşme sağlamaktadır (15). Türkiye'de her geçen gün hemodiyaliz tedavisi uygulanan kişi sayısının artması (2) nedeniyle hastaların konfor düzeyine etki eden faktörlerin belirlenmesi önem kazanmaktadır (16). Çünkü bu faktörler hasta konfor düzeylerinin bozulmasına ve zarar görmesine neden olmaktadır (16). Bu çalışma hemodiyaliz tedavisi alan hastalarda yaşanan semptomların konfor düzeyine etkisini incelemek amacıyla yapılmıştır.

\section{GEREÇ VE YÖNTEM}

\section{Araştırmanın Tipi}

Tanımlayıcı ve kesitsel tipte bir araştırmadır.

\section{Araştırmanın Yeri ve Zamanı}

Çalışma, İstanbul'un Avrupa yakasında yer alan bir HD merkezinde HD tedavisi alan hastalarla Kasim 2020-Mart 2021 tarihleri arasında yapıldı.

\section{Araştırmanın Evreni ve Örneklemi}

Araştırmanın evrenini, çalışmanın yapıldığı tarihlerde HD ünitesinde tedavisi alan 210 hasta oluşturdu. Dahil edilme kriterlerini sağlayan 192 (\%95 katılım) hastayla veri toplama işlemi gerçekleştirildi. Örneklem büyüklüğünün yeterli olduğunu belirlemek için G-Power 3.1. programı kullanılarak yapılan güç analizinde araştırmanın \%95 güven aralığında, 0,05 anlamlılık düzeyinde etki büyüklüğü 0,256 , gücü ise 0,95 olarak belirlendi. Bu değerler örneklem büyüklüğünün istendik düzeyde olduğuna işaret etmektedir (17).

\section{Dahil edilme kriterleri}

- Çalışmaya katılmaya gönüllü olma

- 18 yaş ve üzerinde olma
- En az 6 aydir HD tedavisi alma

- Veri toplama araçlarının cevaplayabilecek bilişsel yeterliliği olma

- İletişim problemi olmama (işitme, dil, anlama vb.)

- Psikiyatrik hastalık, akut enfeksiyon, akut kalp yetmezliği ya da serebral vasküler hastalık öyküsü olmama

\section{Veri toplama araçları}

Çalışma verileri, "Hasta Tanıtım Formu", "Diyaliz Semptom İndeksi" ve "Hemodiyaliz Konfor Ölçeğii" ile toplandı. Veriler yüz yüze görüşme yoluyla ve ortalama 5-10 dakika arasında toplandi. Hastalar HD cihazına bağlandıktan ve durumları stabilleştikten sonra veri toplama araçları araştırmacı tarafından dolduruldu. Verilerin toplanmasinda COVID-19 pandemi koşulları göz önünde bulundurularak gerekli önlemler (maske, mesafe ve hijyen) alındı.

Hasta Tanıtım Formu: Araştırmaya katılan hastaların sosyodemografik, sağl1k ve hastalıkla ilgili özelliklerini belirlemek için araştırmacı tarafından hazırlanan "Hasta Tanıtım Formu" kullanılmıştır. Bu form toplam 12 sorudan oluşmaktadır. Literatür taranarak hazırlanan formda yaş, cinsiyet, medeni durum, gelir durumu, eğitim durumu, çalışma durumu, sigara ve alkol kullanma durumu, HD tedavi yıl1, kronik böbrek yetmezliği dışındaki hastalıklar, egzersiz yapma durumu sağlık durumu hakkında sorular yer almaktadır $(4,5,7)$.

Diyaliz Semptom İndeksi: Diyaliz Semptom İndeksi (DSI) Weisbord ve ark. (2005) tarafindan HD hastalarının yaşadıkları semptomları ve hastaları etkileme düzeyini belirlemek amacıyla geliştirmiştir (18). Ölçeğin Türkçe güvenilirlik ve geçerliği Önsöz ve Yeşilbalkan (2013) tarafından yapılmış ve Cronbach's alpha değeri 0,84 olarak bildirilmiştir (19). DSİ, fiziksel ya da duygusal olarak 30 semptomu tanımlamaktadır. DSİ'de son bir hafta içerisinde yaşanılan semptomlara evet-hayır olarak yanıt verilmekte, yanıt evet ise bu semptomların ne kadar etkilediği, beşli Likert olarak " $0=$ hiç, $4=$ çok fazla" şeklinde değerlendirilmektedir. Ölçekten 0-150 arasında puan alınmakta ve alınan puanlar artıkça semptom şiddetinin arttığını göstermektedir. Bu 
çalışmada ölçeğin Cronbach's alpha değeri 0,67 olarak saptand1.

Hemodiyaliz Konfor Ölçeği: Orak ve ark. (2017) tarafindan "Genel Konfor Ölçeği”" baz alınarak geliştirilen ve güvenilirlik ve geçerliği yapılan "Hemodiyaliz Konfor Ölçeği (HKÖ)", en az altı ay hemodiyaliz tedavisi uygulanan hastaların konforunun değerlendirilmesinde kullanılmaktadır. HKÖ beşli Likert tipinde bir ölçme aracı olup, 9 madde ve iki alt boyuttan (Rahatlama (3 madde)" ve "Üstesinden gelme (6 madde)") oluşmaktadır. Ölçekte maddeler "hiçbir zaman" 5- "her zaman" 1 şeklinde puanlanmaktadır. HKÖ 9-45 arasında, rahatlama alt boyutundan 3-15 ve üstesinden gelme alt boyutundan ise 6-30 puan alınmaktadır. Alınan puanın artması konfor seviyesinin yükseldiğini göstermektedir. HKÖ'nün Cronbach's alpha değerinin 0,87 olduğu bildirilmiştir (5). Bu çalışmada ölçeğin Cronbach's alpha değeri 0,67 olarak saptandı.

\section{Verilerin Değerlendirilmesi}

Araştırmada elde edilen verilerin değerlendirilmesi SPSS 25 paket programında yapıldı. Değişkenlere ilişkin tanımlayıcı istatistikler yüzdeler, sayı, ortalama ve standart sapma olarak verildi. Ölçeklerden alınan puanlar standart sapma, ortalama, minimum ve maksimum değerler olarak verildi. Semptom yüklerini belirlemede Bartlett Testleri, KaiserMeyer-Olkin İndeksi (KMO), Doğrulayıcı Faktör Analizi (DFA) yöntemleri kullanıldı. Sayısal değişkenlerin normal dağılıma uygunluğu Skewness ve Kurtosis ile değerlendirildi. Skewness ve Kurtosis değerlerine göre normal dağılıma ( -2 ile +2 arasında) sahip olmayan değişkenler arasında ilişkiyi belirlemek için Sperman's korelasyon analizi kullanıldı. HD hastalarının konfor düzeyini etkileyen belirleyicilerin ilişkisini ele almak için çoklu doğrusal regresyon analizi yapıldı. Elde edilen bulgular \%95 güven aralığında, \%5 anlamlılık düzeyinde değerlendirildi.

\section{Araştırmanın Etik Boyutu}

Araştırmayı yapabilmek için İstanbul Sabahattin Zaim Üniversitesi Etik Kurul Başkanlığı'ndan (25. 11.2019 tarih 2019/11 say1) onay alınd1. Örnekleme dahil edilen tüm hastalara araştırma öncesinde çalışmanın amacına yönelik gerekli açıklamalar yapıldı, açıklama sonrasında bilgilendirilmiş onam formu doldurularak yazılı izin alındı. İlgili HD ünitesinden araştırmanın yapılmasına dair kurum izni (10.11.2020 tarih 140 sayı) alındı. Bu çalışma Helsinki Bildirgesi'ne uygun olarak yapıld1. Gönüllü bireyler araştırmaya dahil edildi ve kişisel bilgileri gizli tutuldu.

\section{BULGULAR}

Hastaların yaş ortalaması $54,6 \pm 10,69$, hemodiyaliz tedavi süresi ortalamas1 3,21 $\pm 1,54$ y1l olup \%50'si erkek, \%80,4'ü evli, \%29,8'i ilköğretim mezunu, $\% 63,5$ 'i sigara ve $\% 86,5$ 'i alkol kullanmamaktadır. Hastaların \%74,8'i KBY dişında hipertansiyon hastalığının olduğunu, \%68,6'sı egzersiz yapmadığını, $\% 71,1$ 'i sağlik durumunu iyi olarak değerlendirdiğini ve \%41,7'si bir y1l öncesine göre sağlık durumunun hemen hemen aynı olduğunu bildirmiştir (Tablo 1).

Çalışmada hastaların en çok deneyimlediği semptomların yorgunluk $(\% 72,6)$, rahatsızlık $(\% 56,5)$ ve kayg1lı olma $(\% 47,9)$; en az deneyimlediği semptomların kusma (\%1), öksürük $(\% 5,8)$ ve nefes darlığ 1 $(\% 6,3)$ olduğu saptandı (Tablo 2).

Diyaliz Semptom İndeksi ortalamas1 18,9 $\pm 10,31$; HKÖ ortalamas1 $32,87 \pm 4,28$, üstesinden gelme alt boyut ortalamasi $20,51 \pm 2,91$ ve rahatlama alt boyut ortalaması 12,36 $\pm 2,6$ olarak saptandı (Tablo 3).

Faktör analizi yapılmadan önce, örneklem büyüklügünün yeterli olduğunu ve faktör korelasyon matrisinin uygun olduğunu değerlendirmek için "KMO örnekleme yeterlilik testi" ve "Bartlett'in küresellik testi” yapıld1. DSI'nin KMO katsayıs1 0,628, Bartlett's testi $\mathrm{p}<0,001$ olarak bulundu. $\mathrm{Bu}$ sonuca göre örneklem büyüklügünün faktör analizi için yeterince büyük olduğu saptandı. Bu çalışmada faktör analizi olarak DFA kullanılmış ve faktör sayısının tespit edilmesinde özdeğeri biri geçen bileşenler ele alındı. DFA sonucuna göre, ölçeğin özdeğeri biri geçen sekiz faktörlü bir yapıda olduğu saptandı. Özdeğeri 3,81 olan 1. faktör toplam varyansın $\% 12,7$ 'sini, özdeğeri 1,21 olan 8. faktör toplam 
varyansın \%4,05'ini ve bu sekiz faktörlü yapının ise toplam varyansın \%54,41'ini açıkladığı belirlendi (Tablo 4).

Tablo 1. Hastaların Sosyodemografik ve Hastalık Özellikleri (n:192)

\begin{tabular}{|c|c|c|c|}
\hline & & Ort \pm SS & Min-Max (Median) \\
\hline \multicolumn{2}{|l|}{ Yaş } & $54,6 \pm 10,69$ & $28-78(53)$ \\
\hline \multicolumn{2}{|l|}{ Hemodiyaliz Süresi (Yıl) } & $3,21 \pm 1,54$ & $1-10(3)$ \\
\hline & & $\mathbf{n}$ & $\%$ \\
\hline \multirow{2}{*}{ Cinsiyet } & Kadın & 96 & 50,0 \\
\hline & Erkek & 96 & 50,0 \\
\hline \multirow{2}{*}{ Medeni Durum } & Evli & 152 & 80,4 \\
\hline & Bekar & 37 & 19,6 \\
\hline \multirow{6}{*}{ Eğitim Durumu } & Okur yazar değil & 1 & 0,5 \\
\hline & Okur yazar & 21 & 11,0 \\
\hline & İlk öğretim & 57 & 29,8 \\
\hline & Orta öğretim & 45 & 23,6 \\
\hline & Lise & 46 & 24,1 \\
\hline & Yüksek öğretim ve üstü & 21 & 11,0 \\
\hline \multirow{3}{*}{ Gelir Düzeyi } & Gelir giderden fazla & 78 & 41,9 \\
\hline & Gelir gidere eşit & 71 & 38,2 \\
\hline & Gelir giderden az & 36 & 19,4 \\
\hline \multirow{2}{*}{ Çalışma Durumu } & Evet & 66 & 34,6 \\
\hline & Hayır & 125 & 65,4 \\
\hline \multirow{2}{*}{$\begin{array}{l}\text { Sigara Kullanma } \\
\text { Durumu }\end{array}$} & Evet & 70 & 36,5 \\
\hline & Hayır & 122 & 63,5 \\
\hline \multirow{2}{*}{ Alkol Kullanma Durumu } & Evet & 26 & 13,5 \\
\hline & Hayır & 166 & 86,5 \\
\hline \multirow{5}{*}{$\begin{array}{l}\text { Kronik Böbrek Yetmezliği Dışındaki } \\
\text { Hastalıklar }\end{array}$} & Diyabet & 28 & 25,2 \\
\hline & Hipertansiyon & 83 & 74,8 \\
\hline & Kalp arter hastalığı & 19 & 17,1 \\
\hline & КОАН & 5 & 4,5 \\
\hline & Nörolojik hastalık & 1 & 0,9 \\
\hline \multirow{2}{*}{ Egzersiz Yapma Durumu } & Evet & 59 & 31,4 \\
\hline & Hayır & 129 & 68,6 \\
\hline \multirow{3}{*}{ Sağlık Durumu } & İyi & 135 & 71,1 \\
\hline & Orta & 54 & 28,4 \\
\hline & Kötü & 1 & 0,5 \\
\hline
\end{tabular}

KOAH: Kronik Obstrüktif Akciğer Hastalığ 1 
Alkın Demir \& Özer; Hemodiyaliz Hastalarında Konfor ve Semptom İlişkisi

Tablo 2. Hastaların Diyaliz Semptom İndeksine Göre Yaşadıkları Semptomların Sıklığı (n:192)

\begin{tabular}{|c|c|c|}
\hline Diyaliz Semptomları & $\mathbf{n}$ & $\%$ \\
\hline Yorgunluk & 138 & 72,6 \\
\hline Rahatsızlık & 108 & 56,5 \\
\hline Kaygilı olma & 90 & 47,9 \\
\hline Kemik-eklem ağrısı & 82 & 42,9 \\
\hline Baş ağrısı & 80 & 41,7 \\
\hline Endişelenme & 78 & 40,8 \\
\hline Ayakta uyuşukluk & 62 & 32,5 \\
\hline Baş dönmesi & 60 & 31,6 \\
\hline Uykuya dalmada zorluk & 60 & 31,3 \\
\hline Bacakları hareketsiz tutmada zorlanma & 57 & 29,7 \\
\hline Cinsel ilgide azalma & 56 & 29,2 \\
\hline Üzgün olma & 53 & 28 \\
\hline Kas ağrısı & 43 & 22,5 \\
\hline Sinirli olma & 37 & 19,4 \\
\hline Konsantre olmada zorluk & 34 & 17,7 \\
\hline İştahsızlık & 33 & 17,2 \\
\hline Uyku sürdürme zorluğu & 31 & 16,2 \\
\hline Cinsel doyumda zorlanma & 31 & 16,1 \\
\hline Ăğız kuruluğu & 30 & 15,6 \\
\hline İshal & 27 & 14,1 \\
\hline Kabızlık & 25 & 13 \\
\hline Kas krampları & 24 & 12,6 \\
\hline Bacakta şişlik & 22 & 11,5 \\
\hline Göğüs ağrısı & 20 & 10,4 \\
\hline Kaşıntı & 19 & 9,9 \\
\hline Deride kuruluk & 15 & 7,8 \\
\hline Bulantı & 12 & 6,3 \\
\hline Nefes darlığı & 12 & 6,3 \\
\hline Öksürme & 11 & 5,8 \\
\hline Kusma & 2 & 1 \\
\hline
\end{tabular}

Tablo 3. Hastaların Hemodiyaliz Konfor Ölçeği ve Alt Boyutları ile Diyaliz Semptom İndeksi Ölçüm Ortalamaları (n:192)

\begin{tabular}{|l|c|c|}
\cline { 2 - 3 } \multicolumn{1}{c|}{} & Ort \pm SS & Min-Max (Median) \\
\hline Diyaliz Semptom İndeksi & $18,9 \pm 10,31$ & $2-65(17)$ \\
\hline Üstesinden Gelme & $20,51 \pm 2,91$ & $9-27(21)$ \\
\hline Rahatlama & $12,36 \pm 2,6$ & $5-15(13)$ \\
\hline Hemodiyaliz Konfor Ölçek Toplamı & $32,87 \pm 4,28$ & $20-41(33)$ \\
\hline
\end{tabular}


Tablo 4. Diyaliz Semptom İndeksinin Faktör Yüklerine Göre Dağılımı

\begin{tabular}{|c|c|c|c|c|c|c|c|c|}
\hline & $\begin{array}{c}1 . \\
\text { Faktör }\end{array}$ & $\begin{array}{c}2 . \\
\text { Faktör }\end{array}$ & $\begin{array}{c}3 . \\
\text { Faktör }\end{array}$ & $\begin{array}{c}4 . \\
\text { Faktör }\end{array}$ & $\begin{array}{c}5 . \\
\text { Faktör }\end{array}$ & $\begin{array}{c}6 . \\
\text { Faktör }\end{array}$ & $\begin{array}{c}7 . \\
\text { Faktör }\end{array}$ & $\begin{array}{c}8 . \\
\text { Faktör }\end{array}$ \\
\hline Bacakları Hareketsizlikte Zorlama & 0,713 & & & & & & & \\
\hline Bacakta Şişlik & 0,705 & & & & & & & \\
\hline Ayakta Uyuşukluk & 0,649 & & & & & & & \\
\hline Kramp & 0,523 & & & & & & & \\
\hline Deride Kuruluk & & 0,835 & & & & & & \\
\hline Kaşıntı & & 0,823 & & & & & & \\
\hline Kayg1lı olma & & & 0,916 & & & & & \\
\hline Endişelenme & & & 0,876 & & & & & \\
\hline Konsantrede Zorluk & & & $-0,689$ & & & & & \\
\hline Sinirli Olma & & & 0,776 & & & & & \\
\hline Üzgün Olma & & & 0,512 & & & & & \\
\hline Cinsel İlgide Azalma & & & & 0,915 & & & & \\
\hline Cinsel Doyumda Zorlanma & & & & 0,849 & & & & \\
\hline Kusma & & & & & 0,809 & & & \\
\hline Bulant1 & & & & & 0,698 & & & \\
\hline İştahsızlık & & & & & 0,578 & & & \\
\hline Kabızlık & & & & & $-0,466$ & & & \\
\hline İshal & & & & & $-0,504$ & & & \\
\hline Ağız Kuruluğu & & & & & 0,461 & & & \\
\hline Uykuya Dalmada Zorluk & & & & & & $-0,774$ & & \\
\hline Uyku Sürdürme Zorluğu & & & & & & $-0,541$ & & \\
\hline Göğüs Ağrıs1 & & & & & & & 0,662 & \\
\hline Öksürme & & & & & & & 0,583 & \\
\hline Nefes Darlığ 1 & & & & & & & 0,533 & \\
\hline Baş Ağris1 & & & & & & & & 0,755 \\
\hline Kemik/eklem Ağrısı & & & & & & & & $-0,505$ \\
\hline Kas Ağrıs1 & & & & & & & & $-0,5$ \\
\hline Özdeğeri & 3,81 & 2,96 & 2,06 & 1,79 & 1,59 & 1,49 & 1,39 & 1,21 \\
\hline Açıkladığı Varyans & 12,7 & 9,88 & 6,88 & 5,97 & 5,32 & 4,96 & 4,65 & 4,05 \\
\hline Kaiser-Meyer-Olkin & Sampli & g Adequ & & & & & \multicolumn{2}{|c|}{0.628} \\
\hline \multicolumn{6}{|c|}{ Bartlett's Test of Sphericity } & $\begin{array}{r}\mathrm{X}^{2} \\
\mathrm{Sd} \\
\mathrm{p}\end{array}$ & & $\begin{array}{r}471,989 \\
435 \\
0,001\end{array}$ \\
\hline
\end{tabular}

Bağımsız değişkenlerin HKÖ üzerindeki etkisini belirlemek amacıyla gerçekleştirilen çoklu doğrusal regresyon analizi sonuçlarının istatistiksel olarak anlamlı olduğu saptandı $(\mathrm{F}=8,724, \mathrm{p}<0,001)$. Modelde yer alan bağımsız değişken HKÖ toplam varyansın $\% 22,1$ 'ini açıklamaktadır $(\mathrm{p}<0,01)$. Regresyon katsayıları incelendiğinde 1. faktör (bacakları hareketsiz tutmakta zorlanma, bacakta şişlik, ayakta uyu- şukluk, kramp), 3. faktör (kaygıılı olma, endişelen-me, konsantrede zorluk, sinirli olma, üzgün olma) ve 5. faktör (kusma, bulantı, iştahsızlık, kabızlık, ishal, ağız kuruluğu) değişkenlerinin HKÖ'ye negatif yönde ve anlamlı etki ettiği saptandı (Tablo 5). 
Tablo 5. Bağımsız Değişkenler ile Hemodiyaliz Konfor Ölçeğinin Yordanması için Çoklu Doğrusal Regresyon Analizi Bulguları

\begin{tabular}{|c|c|c|c|c|c|c|}
\hline \multirow[b]{2}{*}{ Model } & \multirow[b]{2}{*}{ Değişkenler } & \multicolumn{5}{|c|}{ Multivariable } \\
\hline & & B & S.Hata & Standart (B) & $\mathbf{t}$ & $\mathbf{p}$ \\
\hline \multirow{3}{*}{1} & 1.Faktör & $-0,29$ & 0,143 & $-0,193$ & $-2,019$ & $0,045^{*}$ \\
\hline & 3.Faktör & $-0,38$ & 0,107 & $-0,322$ & $-3,541$ & $0,001 *$ \\
\hline & 5.Faktör & $-0,424$ & 0,152 & $-0,213$ & $-2,792$ & $0,006 *$ \\
\hline \multicolumn{7}{|c|}{$F=8,724 \quad R=0,471 \quad R 2=0.221 \quad * p<0,05$} \\
\hline
\end{tabular}

\section{TARTIŞMA}

Son dönem böbrek yetmezliğinin tedavisinde vazgeçilmez bir parça olan HD’ye bağlı ortaya çıkan semptomlar ve ek sorunlar hastaların yaşamlarında ciddi değişikliklere neden olmaktadır. Hastaların tedavi sürecinde diyet ve sıvı alımı, uyku düzeni, sosyal aktivite, psikolojik ihtiyaçlar ve fiziksel yeterlilikler gibi birçok faktör etkilenmekte ve değişmektedir. $\mathrm{Bu}$ semptomlara uyum sağlayabilen hastalar hastalığını daha iyi yönetebilmekte ve konforlarını arttırabilmektedir $(15,21)$. Bu çalışma hemodiyaliz tedavisi alan hastalarda yaşanan semptomların konfora etkisini incelemek amacıyla yapılmıştır.

$\mathrm{Bu}$ çalışmada hastaların en çok yorgunluk, rahatsızlık, kaygılı olma, kemik-eklem ağrısı, baş ağrısı, endişelenme semptomları yaşadıkları saptandı. Yorgunluk, kemik-eklem ağrısı, baş ağrısı ve endişelenme yapılan farklı çalışmalarda hastaların en sık yaşadığ1 semptomlar olarak bildirilmiştir $(4,6,7,22$ 24). Rahatsızlık ve kayg1lı olma semptomları ise başka çalışmalarda $(4,6)$ en sık olmasa da bu çalışmada; hastalarda hastalığa ve tedaviye bağlı olarak vücutta meydana gelen fizyopatolojik değişimlerden (25) dolayı en sik deneyimlenen semptomlardır.

$\mathrm{Bu}$ çalışmada hastaların diyaliz semptom şiddeti düşük bulunmuştur. Yapılan farklı bir çalışmada, hasta bireylerin DSI'den aldıkları puana göre semptom şiddeti yüksek olarak bildirilmiştir (23). Akgöz ve Arslan (2017), Dikmen ve Aslan (2020) ve Demiroğlu ve Bülbül (2021)'ün yaptıkları çalışmalarda, hastalar tarafindan ifade edilen diyaliz semptom şiddetlerinin orta seviyede olduğu belirtilmiştir (26-28). Yılmaz ve ark.'nın (2020) yapmış olduğu araştırmada hastaların yaşadıkları semptom- ların düşük düzeyde olduğu bildirilmiştir (29). Bu çalışmada hastaların orta yaş grubunda olması ve HD'ye başlama tedavi sürelerinin kısa olmasının semptom şiddetlerinin düşük olmasına ve çalışmaların farklı bölgelerde yapılmasının sonuçlarda farklılaşmaya neden olabileceği düşünülmektedir.

$\mathrm{Bu}$ çalışmada HKÖ, Üstesinden Gelme ve Rahatlama alt boyut ortalamaları orta düzeyde bulunmuştur. Hastaların, konfor düzeylerinin orta seviyede olduğu saptanmıştır. Şentürk'ün (2021), Gülay ve ark.'nın (2020) ve Çalışkan ve Çınar Pakyüz'ün (2019) yaptıkları çalışmada hastaların HKÖ ortalamalarının orta düzeyde olduğu bulunmuştur (30-32). Yapılan farklı çalışmalarda da hemodiyaliz hastalarının konfor düzeylerinin orta seviyede olduğu bildirilmiştir $(14,15)$. Dikmen ve Aslan'1n (2020) yaptıkları çalışmada hastaların konfor seviyelerinin orta seviyenin altında olduğu bildirilmiştir (27). Bu çalışmada konfor düzeyinin orta seviyede saptanması HD'ye başlama sürelerinin kısa olması ile ilişkilendirilmiştir. Ayrıca HD tedavisi alan hastalar yaşamlarının büyük bölümünü HD ünitelerinde geçirdiklerinden, farklı mental ve fiziksel sağlık problemleriyle baş etmeleri gerektiğinden ve sıvı ve diyet kisitlamalarından dolayı konfor düzeyleri olumsuz etkilenebilmektedir (33).

$\mathrm{Bu}$ çalışmada, hastaların yaşadıkları kas iskelet sistemi (bacakları hareketsiz tutmada zorlanma, bacakta şişlik, ayakta uyuşukluk, kas krampları), emosyonel (kaygılı olma, endişelenme, konsantre olmada zorluk, sinirli olma, üzgün olma) ve gastrointestinal sistem (kusma, bulantı, iştahsızlık, kabızlık, ishal, ağız kuruluğu) semptomları konfor düzeyini olumsuz etkilemektedir. Çalışmamıza benzer şekilde Dikmen ve Aslan'1n (2020) ve Freire ve ark. (2020) 
yaptıkları çalışmada yaşanılan kas iskelet sistemi, emosyonel, gastrointestinal sistem semptomlarının hastaların konfor düzeylerini olumsuz etkilediği bildirilmiştir (16,27). Hastaların yaşadıkları semptomlar HD sirasinda ve sonrasinda da devam etmektedir. Yaşanan bu semptomlar hemen hemen her HD seansı esnasında tekrarlanmakta; ağrı, kas krampları ve ağız kuruluğu gibi semptomlar kronikleşebilmektedir. Bu semptomların sürekli yaşanması hastaların günlük yaşamlarını, çevreleri ile olan ilişkilerini ve konfor düzeylerini olumsuz etkileyebilmektedir $(15,27)$.

\section{Araştırmanın Sınırlılıkları}

$\mathrm{Bu}$ çalışmanın birinci sınırlılığı; çalışmanın sonuçları sadece çalışmaya dahil edilen hastalar için geçerlidir; bu nedenle tüm hastalara genellenemez. İkinci sınırlılığı; verilerin güvenilirliği, araştırmaya katılan tüm hastaların vermiş oldukları yanıtların doğruluğu ile sınırlıdır. Üçüncü sınırlılığı; araştırmanın sadece bir merkezde yapılmasıdır.

\section{SONUÇ ve ÖNERILER}

Hastaların en çok yorgunluk, rahatsızlık, kaygılı olma, kemik-eklem ağrısı, baş ağrısı, endişelenme semptomları yaşadıkları saptanmıştır. Hastaların semptom şiddetinin düşük, konfor düzeylerinin orta seviyede olduğu saptanmıştır. HD alan hastaların en sık yaşadıkları semptomları hafifletmek amaciyla semptom yönetimi konusunda HD merkezinde çalışan hemşirelere eğitimlerin verilmesi, konfor seviyesini yükseltmek amaciyla HD ünitelerinde ergonomik koşulların düzenlenmesi gerekmektedir. Hastaların yaşadıkları bacakları hareketsiz tutmada zorlanma, bacakta şişlik, ayakta uyuşukluk, kas krampları, kaygılı olma, endişelenme, konsantre olmada zorluk, sinirli olma, üzgün olma, kusma, bulant1, iştahsızlık, kabızlık, ishal, ağız kuruluğu semptomları konfor düzeyini olumsuz etkilemektedir. $\mathrm{Bu}$ bulgular doğrultusunda; hastaların yaşadıkları semptomların ve konfor düzeylerinin belli aralıklarla sorgulanması, hastaların tedavi sürecinde deneyimledikleri semptomlarla baş edebilmesinde ve konforun artırılmasında hasta odaklı bir yaklaşım ile hastaya destek verilmesi önerilmektedir.

\section{Etik Komite Onayı}

Bu çalışma için etik komite onayı, İstanbul Sabahattin Zaim Üniversitesi Etik Kurul Başkanlığı'ndan alınmıştır (Tarih ve no: 25.11.2019 tarih 2019/11 say1).

\section{Bilgilendirilmiş Onam}

Çalışmaya katılan hastaların yazılı ve sözlü onamları alınmıştır.

\section{Çıkar Çatışması Beyanı}

Çalışma ile ilgili herhangi bir mali ya da diğer çıkar çatışması bulunmamaktadır.

\section{Finansal destek}

Çalışma ile ilgili herhangi bir kurum/ kuruluşun desteği bulunmamaktadır.

\section{Kaynaklar}

1. Topbaş E. Kronik böbrek hastalığının önemi, evreleri ve evrelere özgü bakımı. Nefroloji Hemşireliği Dergisi. 2015; 53-9.

2. Süleymanlar G, Ateş K, Seyahi N. Ulusal Nefroloji, Diyaliz ve Transplantasyon Registry Raporu 2020, Türk Nefroloji Derneği Yayınları, Ankara, 2021. https://nefroloji.org.tr/uploads/folders/file/REGISTRY_2020.pdf

3. Yürügen B, Gökdoğan F, Nural N. Diyaliz Teknikerleri için Nefroloji Kitabı. Birinci Baskı. Akademisyen Tıp Kitabevi, Ankara; 2015; 1-182. 
4. Hintistan S, Deniz A. Evaluation of symptoms in patients undergoing hemodialysis. Bezmialem Science. 2018 ; 6: 112-8. https://doi.org/10.14235/bs.2018.1530

5. Orak NŞ, Pakyüz SÇ, Kartal A. Ölçek geliştirme çalışması: Hemodiyaliz hastalarında konfor. Nefroloji Hemşireliği Dergisi. 2017; 12(2): 68-77.

6. Almutary H, Bonner A, Douglas C. Which patients with chronic kidney disease have the greatest symptom burden? A comparative study of advanced CKD stage and dialysis modality. Journal of renal care. 2016; 42(2):73-82. https://doi.org/10.1111/jorc.12152

7. Göriş S, Ceyhan Ö, Taşcı S, Doğan N. Do symptoms related to hemodialysis affect marital adjustment?. Sexuality and Disability. 2016; 34(1): 63-73. https://doi.org/10.1007/s11195-016-9428-x

8. Terzi B, Kaya N. Konfor kuramı ve analizi. Anadolu Hemşirelik ve Sağlık Bilimleri Dergisi. 2017; 20(1): 67-74

9. Yücel ŞÇ. Kolcaba'nın konfor kuramı. Ege Üniversitesi Hemşirelik Fakültesi Dergisi. 2011; 27 (2):79-88. Retrieved from https://dergipark.org.tr/tr/pub/egehemsire/issue/49355/630403

10. Kolcaba K. Katharine Kolcaba's comfort theory. In: Parker M, Smith M, eds. Nursing Theories \& Nursing Practice. 3 rd ed. Philadelphia: Elsevier; 2015: 389-401.

11. Kolcaba K. Definitions of concepts in Kolcaba's middle range: theory of comfort. 2010. http://www.thecomfortline.com/ home/faq.html Erişim tarihi: 19.01.2022

12. Wilkinson MJ, Barcus L. PEARSON hemşirelik tanıları el kitabı. In: Kapucu S, Akyar İ, Korkmaz F, editors. 11 nt ed. Ankara: Pelikan Yayınevi; 2018. p. 1081-1087

13. Arslankılıç Ç, Göl E. Kolcaba'nın konfor kuramının cerrahi operasyon geçiren hastalarda kullanımı: Sistematik derleme. Türkiye Sağlık Bilimleri ve Araştırmaları Dergisi. 2020; 3(1):34-44.

14. Melo GAA, Aguiar LL, Silva RA, Quirino GDS, Pinheiro AKB, Caetano JÁ. Factors related to impaired comfort in chronic kidney disease patients on hemodialysis. Revista brasileira de enfermagem. 2019; 72:889-95. https://doi.org/10.1590/0034-7167-20180120

15. Estridge KM, Morris DL, Kolcaba K, Winkelman, C. Comfort and fluid retention in adult patients receiving hemodialysis. Nephrology Nursing Journal. 2018; 45(1):25- 33

16. Freire SDML, Melo GAA, Lima MMDS, Silva RA, Caetano JÁ, Santiago JCDS. Contexts of experience of being (un) comfortable in patients with chronic kidney disease. Escola Anna Nery. 2020;24. https://doi.org/10.1590/2177-9465-EAN-2019-0326

17. Çapık C İstatistiksel güç analizi ve hemşirelik araştirmalarinda kullanımı: Temel bilgiler. Anadolu Hemşirelik ve Sağlık Bilimleri Dergisi. 2014; 17(4):268-74.

18. Weisbord SD, Fried LF, Arnold RM, Fine MJ, Levenson DJ, Peterson RA, et al. Prevalence, severity, and importance of physical and emotional symptoms in chronic hemodialysis patients. J Am Soc Nephrol. 2005; 16(8): 2487-94.

19. Önsöz HB, Usta Yeşilbalkan Ö. Reliability and validity of the turkish version of the dialysis symptom index in chronic hemodialysis patients. Turkish Nephrology, Dialysis and Transplantation Journal. 2013; 22(1): 60-7.

20. World Medical Association. World medical association declaration of Helsinki ethical principles for medical research involving human subjects. Journal of the American Medical Association. 2013; 310(20): 2191-4.

21. Atik D, Karatepe H, Yuce UO. The relationship between fluid control and disease adaptation levels with symptoms in patients undergoing hemodialysis. Journal of Basic and Clinical Health Sciences. 2020; 4(3):264-71. https://doi.org/10.30621/ jbachs. 2020.974

22. Fleishman TT, Dreiher J, Shvartzman P. Patient-reported outcomes in maintenance hemodialysis: a cross-sectional, multicenter study. Qual Life Res. 2020; 29:2345-54. https://doi.org/10.1007/s11136-020-02508-3

23. Gamondi C, Galli N, Scho“nholzer C, Marone C, Zwahlen H, Gabutti L. et al. Frequency and severity of pain and symptom distress among patients with chronic kidney disease receiving dialysis. Eur. J. Med. Sci. 2013; 143:1-11. https://doi.org/10.4414/smw.2013.13750.

24. Metzger M, Abdel-Rahman EM, Boykin H, Song MK. A narrative review of management strategies for common symptoms in advanced CKD. Kidney Int Rep. 2021;6(4):894-904. https://doi.org/10.1016/j.ekir.2021.01.038

25. Chen MC, Lin CC, Ho YF, Wu CC, Kuo LC. Development and psychometric testing of the Hemodialysis Symptom Distress Scale (HSD-22) to 1dentify the symptom cluster by using exploratory factor analysis. BMC Nephrol. 2021; 22:128. https://doi.org/10.1186/s12882-021-02337-7

26. Akgöz N, Arslan S. Hemodiyaliz tedavisi alan hastalarda yaşanan semptomların incelenmesi. Türk Nefroloji, Diyaliz ve Transplantasyon Hemşireleri Derneği Nefroloji Hemşireliği Dergisi. 2017, 1: 20-8. 
27. Dikmen RD, Aslan H. The Effects of the symptoms experienced by patients undergoing hemodialysis treatment on their comfort levels. J Clin Nephrol Ren Care. 2020; 6:060. https://doi.org/10.23937/2572-3286/1510060

28. Demiroğlu S, Bülbül E. Hemodiyaliz tedavisi alan hastaların depresyon, anksiyete, stres durumları ve diyaliz semptomlarıyla ilişkisi. Nefroloji Hemşireliği Dergisi. 2021; 16(3): 124-33. https://doi.org/10.47565/ndthdt.2021.40

29. Yılmaz FT, Sert H, Kumsar AK, Aygin D, Sipahi S, Genç AB. Hemodiyaliz tedavisi alan hastaların umut düzeyleri, semptom kontrolü ve tedaviye uyumlarının değerlendirilmesi. ACU Sağlık Bil Derg 2020, 11: 35-43. https://doi.org/10.31067/0.2019.197

30. Şentürk Z. (2021) Hemodiyaliz hastalarında sıvı kontrolü ve konfor arasındaki ilişkinin incelenmesi. Aydın Adnan Menderes Üniversitesi Sağlık Bilimleri Enstitüsü Yayınlanmamış Yüksek Lisans Tezi. Aydın Adnan Menderes Üniversitesi.

31. Gülay T, Özdemir Eler Ç, Ökdem Ş, Akgün Çıtak E. Hemodiyaliz Hastalarında Konfor Düzeyinin İncelenmesi. Hacettepe Üniversitesi Hemşirelik Fakültesi Dergisi 2020; 7(2): 122-129. https://doi.org/10.31125/hunhemsire.763155

32. Çalışkan T, Çınar Pakyüz S. Hemodiyaliz tedavisi alan ve almayan üremik hastalarda kaşıntı konforu etkiler mi?. Türk Nefroloji, Diyaliz ve Transplantasyon Hemşireleri Derneği Nefroloji Hemşireliği Dergisi. 2019;14(3):84-96.

33. Sahın CK, Cınar PS. Evaluation of the effect of nutrition-related visual education on the comfort of patients receiving hemodialysis therapy. Revista de Nutrição. 2021; 34 